\title{
The Impact of Using L1 on Foreign Language Acquisition in Japan
}

\author{
Adam Serag \\ Department of Basic Education, English Studies Laboratory, Gifu Pharmaceutical University, Gifu, Japan
}

How to cite this paper: Serag, A. (2017). The Impact of Using L1 on Foreign Language Acquisition in Japan. The Educational Review, USA,1(3), 70-76.

http://dx.doi.org/10.26855/er.2017.03.004

Corresponding author: Adam Serag, $\mathrm{PhD}$, Department of Basic Education, English Studies Laboratory, Gifu Pharmaceutical University, Gifu, Japan.

\begin{abstract}
This paper investigates Japanese learners' perceptions of using L1 in the EFL classroom, and the impact of using L1 in the EFL classroom on foreign language acquisition in Japan. In particular, the paper focuses on the factors influencing the foreign language acquisition of 62, lower level EFL students at a Japanese university. Data were collected through a questionnaire with 20 items using a five-point Likert-type rating scale. Three factors were investigated: the learners' perceptions of using L1 in the EFL classroom, the relationship between using L1 in the EFL classroom and learning attention support, and the relationship between using L1 in the EFL classroom and learning success. The study hypotheses were tested using Pearson product-moment correlation coefficient. Results showed that Japanese learners were in favor of using L1 in the EFL classroom. Significant correlations were found between using L1 in the EFL classroom and both learning attention support, and learning success. Finally, the paper concludes that using L1 in the EFL classroom is an effective teaching strategy when teaching lower level EFL students in Japan.
\end{abstract}

Keywords

L1, EFL classroom, Attention support, Learning success

\section{Introduction}

Many teachers use L1 in the EFL classrooms for providing students with a situation that makes it possible for students to communicate while checking their understanding. This is because teachers do not have to spend so much time trying to explain meanings to learners. The serious discussion over whether English language classrooms should include or exclude students' native language has been a heated argument for a long time (Brown, 2000), and the research findings have not been entirely persuasive either way. According to Ellis (1984) several researchers claimed that L1 use is not needed in EFL teaching and that the overuse of L1 might deprive learners of the L2 input that is of great value. All language classroom input being in the target language is an effective model of language teaching that can ensure that the targeted learning was successful (Chaudron, 1988; Krashen, 1988; Chi, 2000).

The question of using L1 in the EFL classroom finds its theoretical origins in the development of Input and Interaction theory as an amalgamation of Krashen's comprehensible input, Long's (1981) negotiation of meaning and Swain's (1985) notion of forced output (1985). These frameworks propose that vocabulary and grammar acquisition take place through implicit processes that are stimulated by L2 interaction, thus making a case for the exclusion of the L1. Theory of memory suggests that the brain does not have separate language-specific lexicons (Ellis, 2005) and that therefore, both interacting in the L2 and making mental comparisons between the two or more languages will lead to acquisition. 
Learning English in Japan usually involves rote memorization and considering grammatical structures carefully (Gray, et al, 2001). The Japanese learner also often expects a structured approach, with the right answers, and is often less inclined towards learner autonomy (Griffiths in Gray, et al, 2001). While it is possible to argue that this style of learning is not very productive in Western countries, it is important to note that familiarity with this type of learning could be what makes Japanese learners more comfortable, and therefore more likely to learn. Other Japanese cultural factors and expectations can influence the learning of an L2 (Okihara, et al, in Gray, et al, 2001). These include beliefs that teacher-centered learning is better than student-centered learning, and that repetition is necessary for effective learning.

There is a feeling among Japanese university students that the teacher should know the student's mother tongue (Burden, 2000), in some cases as high as $91 \%$ of the study participants (Critchley, 1999). Lower level university students preferred the teacher to know their language while the intermediate level group wanted the teacher to use L1 in the classroom frequently (Burden, 2000). More specifically, intermediate level students did not want L1 used for grammar explanations while they were in favor of using L1 in the EFL classroom to explain the meanings of difficult words. It was suggested a possible reason for the desire not to have grammar taught in L1 was that it brought back bad memories of English lessons from high school (Burden, 2000). The majority of students did, however, want the teacher to use L1 as a means of reaching out to them (Burden, 2000). Although many Japanese students support the idea of using L1 in the English classroom, they realized the dangers of overusing L1, with 87\% of them agreeing that teachers' use of L1 be strictly limited to support activities that are pedagogical in nature (Critchley, 1999).

\subsection{Research Questions}

This paper will answer the following questions:

1) What are the Japanese learners' perceptions of using L1 in the EFL classroom?

2) Are there any correlations between using L1 in the EFL classroom and learning concentration support or learning success?

\subsection{Literature Review}

There is a body of research suggesting that L1 use can assist L2 learning at various proficiency levels, such as providing a sense of security to learners and reducing affective barriers (Auerbach, 1993). Moreover, Vygotskian sociocultural theory (Lantolf, 2000), with its concepts of scaffolding, semiotic mediation, and the Zone of Proximal Development, provides an analytical framework supporting student L1 classroom use. A number of researchers (Lai, 1996; Cole, 1998; Critchley, 1999; Schweers, 1999; Burden, 2001; Tang, 2002; Greggio \& Gil, 2007) have argued that using L1 in the EFL classroom can be useful in assisting English language teaching and learning processes. The literature reviewed has indicated various positive and facilitating functions of using L1 in the EFL classroom by both the teachers and learners such as explaining new vocabulary, explaining grammar, talking about class tasks and assessments and establishing contact with learners.

Attention is the behavioral and cognitive process of selectively concentrating on one aspect of the environment while ignoring other things. Attention has also been referred to as the allocation of processing resources (Anderson, 2004). Visual attention is thought to operate as a two-stage process (Jonides, 1983) in the first stage, attention is distributed uniformly over the external visual scene and processing of information is performed in parallel. In the second stage, attention is concentrated to a specific area of the visual scene, and processing is performed in a serial fashion. Selective auditory attention or selective hearing is a type of selective attention and involves the auditory system of the nervous system. Selective hearing does not involve the sounds that are not heard. However, it is characterized as the action in which people focus their attention on a specific source of a sound or spoken words. The sounds and noise in the sur- 
rounding environment is heard by the auditory system but certain parts of the auditory information are processed in the brain only. Most often, auditory attention is directed at things people would like to hear.

Attention span is the amount of concentrated time on a task without becoming distracted. Most educators and psychologists agree that the ability to focus attention on a task is crucial for the achievement of one's goals (Anderson,2004).Estimates for the length of human attention span are highly variable and depend on the precise definition of attention being used. Transient attention is a short-term response to a stimulus that temporarily attracts/distracts attention. Researchers disagree on the exact amount of human transient attention span; some say it may be as short as 8 seconds (Chavajay, 1999). Selective sustained attention, also known as focused attention, is the level of attention that produces the consistent results on a task over time. Some state that the human attention span is 10 minutes (Johnson, 2004) others state that most healthy teenagers and adults are unable to sustain attention on one thing for more than about 40 minutes at a time, although they can choose repeatedly to re-focus on the same thing (Chavajay, 1999) For time-on-task measurements, the type of activity used in the test affects the results, as people are generally capable of a longer attention span when they are doing something that they find enjoyable or intrinsically motivating (Chavajay, 1999) Attention is also increased if the person is able to perform the task fluently, compared to a person who has difficulty performing the task, or to the same person when he or she is just learning the task. After losing attention from a topic, a person may restore it by taking a rest, doing a different kind of activity, changing mental focus, or deliberately choosing to re-focus on the first part of the topic.

\section{Methodology}

The questionnaire was pilot tested and the Cronbach alpha calculation established the reliability of the instrument with a reading of .810. The study used a random sampling survey of randomly selected students taking the English Communication A. All of them belonged to the low level proficiency group of learners.

The administered questionnaire investigated the learners' perceptions of using L1 in the EFL classroom, the relationship between using L1 in the EFL classroom and learning concentration support, and the relationship between using L1 in the EFL classroom and learning success in Japan. The questionnaire was adapted in Japanese from studies by Schweers (1999), Tang (2002) and Burden (2001) and modified to include a 5-point Likert-type scale, instead of a Yes/No answer type in order to provide detailed results for statistical analysis. The analysis also covered testing for correlation between variables. All the Likert Scale options have been assigned with a value ranging from 1 to 5. For Part B, 1 refers to 'almost never' while 5 refers to 'all the time' while for Parts $\mathrm{C}$ and D, 1 refers to 'strongly disagree' while 5 refers to 'strongly agree'. A cumulative response value of Part B was correlated with the cumulative value of Part C and Part D. These analyses were done using SPSS software.

The hypotheses of this study are:

1) Hypothesis 1: There is a significant relationship between using L1 in the EFL classroom and learning concentration.

2) Hypothesis 2: There is a significant relationship between using L1 in the EFL classroom and learning success.

\section{Results}

\subsection{Questionnaire Analysis}

The questionnaire analysis resulted with 78.9 percent of the respondents indicating that using L1 in the EFL classroom was beneficial when the teachers were checking for understanding. A total of 85.3 percent of the respondents indicated that using L1 in the EFL classroom helped with explaining differences between Japanese and English 
grammar. A total of 74.8 percent of the respondents indicated that using L1 in the EFL classroom was beneficial when explaining the meaning of new English vocabulary while 79.2 percent stated that using L1 in the EFL classroom was necessary when teachers were explaining how to do new activities in class. In addition, a total of 75.9 percent of the respondents stated that using L1 in the EFL classroom was effective when establishing bonds between the classroom teacher and learners. These findings answer the first research question investigating the Japanese learners' perceptions who were found to be in favor of using L1 in the EFL classroom.

\subsection{Using L1 in the EFL Classroom and Learners' Attention}

As shown in Table 1, the large majority of participants indicated that using L1 in the EFL classroom helps them enjoy their English classes, feel more satisfied with their learning outcomes, overcome their worries, and feel more confident about themselves and able to be more focused on their learning in class. In addition, when analysing the learners' perception of the relationship between teachers' code-switching and learners' positive attention support in learning, the result of the product moment correlation analysis (Table 2) indicated a significant correlation, $r=0.587$. Hence, the more teachers code-switch the stronger is the learners' attentive learning. Therefore, there is a significant relationship between teachers' code-switching and positive attentive learning.

Table 1. Using L1 in the EFL classroom and learners' concentration support (summarized).

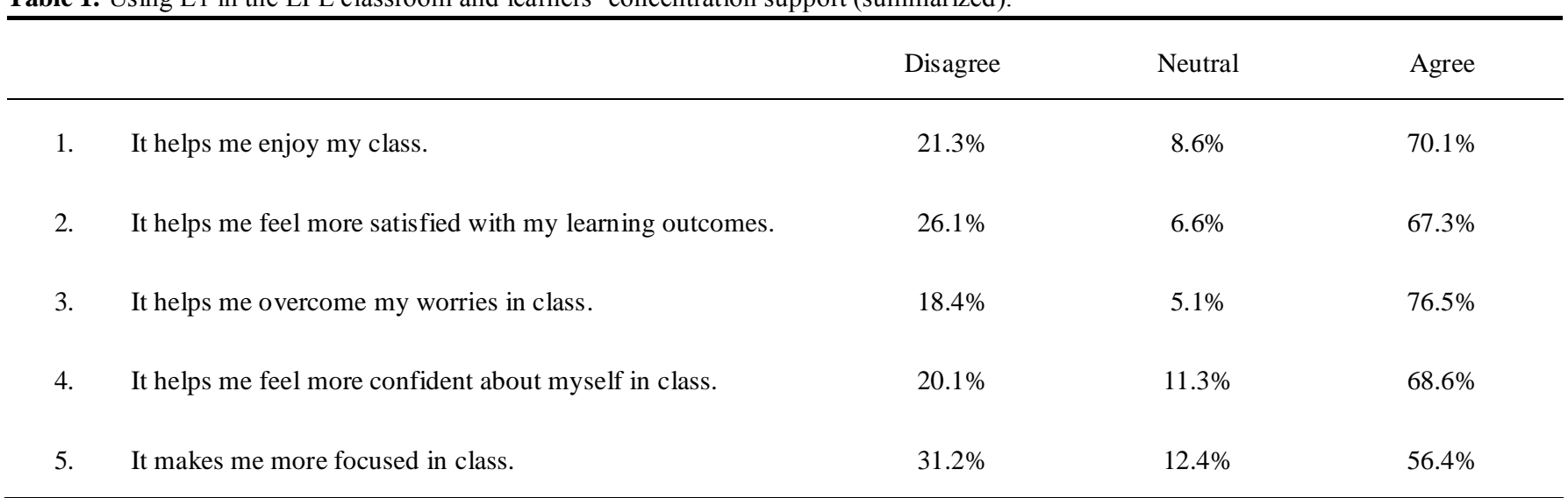

Table 2. Correlation.

Using L1 in the EFL classroom

Learning attention support
38.4163

17.2358

\footnotetext{
* Range 10-50

** Range 5-25

$* * * \mathrm{P} \leq 0.01$
} 
This study found that code-switching helped learners to enjoy their learning because of their ability to fully comprehend the teachers' input. The comprehensible input also allowed them to feel less stressful and to become more comfortable in class. Once they are comfortable with the environment, without any unnecessary anxiety (Lai, 1996; Schweers, 1999; Chi, 2000; Burden, 2001), the learners are able to focus and participate in classroom practice and activities more successfully. Exposure to code-switching at the early stages of learning allows learners (1) to gain a head start towards effective and successful learning and (2) to gradually become users of the target language (Lai, 1996; Cole, 1998; Schweers, 1999; Chi, 2000).

\subsection{Using L1 in the EFL Classroom and Learning Success}

As shown in Table 3, the large majority of participants indicated that using L1 in the EFL classroom supports them to better understand and remember new English vocabulary, difficult written texts and English grammar. In addition, using L1 in the EFL classroom supports their learning as well as their ability to participate successfully in classroom activities. A significant correlation was found $(r=0.640)$ between using L1 in the EFL classroom and learning success as shown in Table 4. Thus, there is a significant relationship between using L1 in the EFL classroom and learning success.

Learning success requires successful provision of comprehensible input to ensure learners understand the intended content, covering new concepts, skills and vocabulary which would consequently be translated into successful completion of tasks (Schweers, 1999; Chi, 2000; Tang, 2002). Learning success reflects the learners' ability to use English effectively as a result of learners' understanding of teachers' input. The anxiety-free classroom atmosphere encourages them to participate more actively in the classroom activities. Therefore, learning success requires successful provision of comprehensible input to ensure learners understand the intended content, covering new concepts, skills and vocabulary which would consequently be translated into successful completion of tasks (Schweers, 1999; Chi, 2000; Tang, 2002). Learning success reflects the learners' ability to use English effectively as a result of learners' understanding of teachers' input generated through learners' successful completion of tasks or activities designed by teachers. An English Only classroom, therefore, cannot always ensure comprehensible input. Hence, code-switching by the teacher should be considered as a form of teaching strategy. This form of classroom instructions fulfils the communicative aspects of the syllabus and teaching approach, by way of achieving the transfer of meaning as aimed by teaching (Skiba, 1997; Cook, 2001; Sert, 2005).

Table 3. Using L1 in the EFL classroom and learners' Learning Success (summarized).

\begin{tabular}{|c|c|c|c|c|}
\hline & & Disagree & Neutral & Agree \\
\hline 2. & It supports me to better understand the difficult written texts. & $17.4 \%$ & $9.1 \%$ & $73.5 \%$ \\
\hline 4. & It supports my learning in class. & $19.9 \%$ & $8.8 \%$ & $71.3 \%$ \\
\hline 5. & It supports me to participate in classroom activities successfully. & $18.9 \%$ & $11.3 \%$ & $69.8 \%$ \\
\hline
\end{tabular}


Table 4. Correlation.

Cumulative Mean Value

Pearson

$R$

Using L1 in the EFL classroom

38.2673

$* *$

Learning Success

18.3313

\footnotetext{
* Range 10-50

** Range 5-25

$* * * \mathrm{P} \leq 0.01$
}

Thus, the above results indicate significant correlations between using L1 in the EFL classroom and both learning attention support, and learning success.

\section{Conclusion}

The analysis of data showed that the large majority of EFL lower level students are in favor of using L1 in the EFL classroom. Students indicated that using L1 in the EFL classroom is beneficial for both their learning attention support and learning success. This work seems to corroborate the findings of Lai (1996), Critchley (1999), Schweers (1999), Dash (2002) and Greggio and Gil (2007) that using L1 in the EFL classroom is a beneficial teaching strategy for ESL lower level and intermediate level classrooms (Critchley, 1998; Tang, 2002; Januleviciene \& Kavaliauskiene, 2002).

The use of code-switching depends on the English proficiency level of learners involved. The study has explored lower level EFL students and the results indicated that these learners were in favor of having the teachers' code-switching in class. However, there are some limitations to the study which investigated only low English proficiency students. A study on intermediate or advanced English proficiency groups of students might produce different responses since students with varying higher levels would need less amount of or even no code-switching from teachers. In addition, the above results are only perceptions from students. The actual relationships between the variables may differ from the outcomes of this study.

\section{References}

Anderson, J. R. (2004). Cognitive Psychology and Its Implications (6th ed.). Worth Publishers, 519. ISBN 978-0-7167-0110-1.

Auerbach, E. R. (1993). Reexamining “English-Only” in the ESL Classroom. TESOL Quarterly, 27, 9-32.

Brown, H. (2000). Principles of Language Learning and Teaching. San Francisco: Longman.

Burden, P. (2000). The Use of the Students' Mother Tongue in Monolingual English "Conversation” Classes at Japanese Universit ies. The Language Teacher, 24(6), 5-10.

Burden, P. (2001). When Do Native English Speakers and Japanese College Students Disagree about the Use of Japanese in the English Conversation Classroom? The Language Teacher, 25(4), 5-9.

Chaudron, C. (1988). Second Language Classrooms: Research on Teaching and Learning. Cambridge: Cambridge University Press.

Chavajay, P., \& Barbara, R. (1999). Cultural Variation in Management of Attention by Children and Their Caregivers. Developmental Psychology, 35 (4): 1079-1090. doi:10.1037/0012-1649.35.4.1079.

Chi, W. C. (2000). The Importance of Bilingual Teachers to Chinese-Oriented AMEP Learners. Presented at the AMEP Conference 2000. http://www.nceltr.mq.edu.au/conference2000.

Critchley, M. (1999). Bilingual Support in English Classes in Japan: A Survey of Student Opinions of L1 Used by Foreign Teachers. The 
Language Teacher, 23(9), 3-13.

Cole, S. (1998). The Use of L1 in Communicative English Classrooms. The Language Teacher, 22(12), 11-13.

Cook, V. (2001). Second Language Learning and Teaching. (3rd ed.). New York: Oxford University Press.

Dash, P. (2002). English Only (EO) in the Classroom: Time for a Reality Check? The Asian EFL Journal, 4(4), 1-20.

Ellis, R. (1984). Classroom Second Language Development. Oxford: Pergamon. New York.

Ellis, N. (2005). At the Interface: Dynamic Interactions of Explicit and Implicit Language Knowledge. Studies in Second Language Acquisition, 27, 305-352

Gray, K., Ansell, M., Cardew, S. \& Leedham, M. eds. (2001). The Japanese Learner: Context, Culture and Classroom Practice. Ox ford: Oxford University Department for Continuing Education.

Greggio, S., \& Gil, G. (2007). Teacher's and Learners' Use of Code Switching in the English as a Foreign Language Classroom: A Qualitative Study. Linguagem \& Ensino, 10(2), 371-393.

Januleviciene, V. \& Kavaliauskiene, G. (2002). Promoting the Fifth Skill in Teaching ESP. English for Specific Purposes World, Web-Based Journal, 1(2).

Jonides, J. (1983). Further towards a Model of the Mind's Eye's movement (PDF). Bulletin of the Psychonomic Society 21(4): 247-250. doi:10.3758/bf03334699.

Johnson, A. (2004). Attention: Theory and Practice. United States of America: SAGE Publications, 1-24. ISBN 978-0-7619-2760-0.

Krashen, S. (1988). Second Language Acquisition and Second language Learning. NY: Prentice Hall.

Krashen, S. (1985). The Input Hypothesis. Longman: London, England.

Laufer, B. \& Shmueli, K. (1997). Memorizing New Words: Does Teaching Have Anything to Do with It? RELC Journal 28(1), 89-108.

Lai, M. L. (1996). Using the L1 Sensibly in English Language Classrooms. Journal of Primary Education, 6(1\&2), 91-99.

Lantolf, J. (ed.) (2000). Sociocultural Theory and Second Language Learning. Oxford: Oxford University Press.

Long, M. H. (1981). Input, Interaction and Second Language Acquisition. In H. Winitz (Ed.), Native Language and Foreign Language Acquisition (259-278). Annals of the New York Academy of Sciences, 379.

Schweers, C. W. (1999). Using L1 in the L2 Classroom. English Teaching Forum, 37(2), 6-13.

Sert, O. (2005). The Functions of Code Switching in Elt Classrooms. The Internet TESL Journal, 10(8). http://iteslj.org/Articles/Sert-CodeSwitching.html.

Skiba, R. (1997). Code Switching as a Countenance of Language Interference. The Internet TESL Journal. 3, 1-6.

Swain, M. (1985). Communicative Competence: Some Roles of Comprehensible Input and Comprehensible Output in Its Development. In Gass, S.and Madden, C. (eds.) Input in Second Language Acquisition. Rowley, MA: Newbury House

Tang, J. (2002). Using L1 in the English Classroom. English Teaching Forum, 40(1), 36-43. 